\title{
Heme oxygenase- 1 activation inhibits XMRV pathogenesis and carcinogenesis in prostate cancer cells
}

\author{
Subhash Dhawan \\ From 15th International Conference on Human Retroviruses: HTLV and Related Viruses \\ Leuven and Gembloux, Belgium. 5-8 June 2011
}

Heme oxygenase-1 (HO-1) induction by hemin, the active ingredient of an FDA-approved biologic for the treatment of acute porphyries, has been previously shown in our laboratory to effectively inhibit HIV-1 replication. The present study was undertaken to expand these observations to examine the inhibitory role of $\mathrm{HO}-1$ in the pathogenesis of XMRV infection. Hemin-induced HO-1 activation in $\mathrm{LNCaP}$, a prostate cancer cell line susceptible to XMRV infection, markedly down-modulated the cell surface expression of XMRV receptor Xpr1, and significantly inhibited their ability to support productive virus replication. Hemin treatment of XMRV-integrated prostate carcinoma cells $22 \mathrm{Rv} 1$ was relatively less effective in suppressing the rapidly replicating XMRV in these aggressive malignant cells; yet it efficiently inhibited XMRV infection of LNCaP cells by about $80 \%$ when cultured for three days in the virus-containing $50 \%$ conditioned media from 22Rv1 cells. Additionally, HO-1 induction retarded the growth of uninfected LNCaP cells, XMRV-infected LNCaP cells and 22Rv1 cells, and significantly reduced their invasiveness to the reconstituted basement membrane matrix Matrigel, consistent with the lower levels of basement membrane degrading enzyme matrix metalloproteinase-9. These findings indicate a pivotal role of HO-1 as a host cell defense mechanism in prostate carcinogenesis in vitro, and may offer $\mathrm{HO}-1$ induction as a potentially novel therapeutic strategy to control the pathogenesis of XMRV infection.

\section{Published: 6 June 2011}

Correspondence: subhash.dhawan@fda.hhs.gov

Laboratory of Molecular Virology, Division of Emerging and Transfusion Transmitted Diseases, Center for Biologics Evaluation and Research, Food and Drug Administration, Bethesda, MD, USA
doi:10.1186/1742-4690-8-S1-A218

Cite this article as: Dhawan: Heme oxygenase- 1 activation inhibits XMRV pathogenesis and carcinogenesis in prostate cancer cells. Retrovirology 2011 8(Suppl 1):A218.
Submit your next manuscript to BioMed Central and take full advantage of:

- Convenient online submission

- Thorough peer review

- No space constraints or color figure charges

- Immediate publication on acceptance

- Inclusion in PubMed, CAS, Scopus and Google Scholar

- Research which is freely available for redistribution

Submit your manuscript at www.biomedcentral.com/submit

\section{() Biomed Central}

\section{Biomed Central}

(c) 2011 Dhawan; licensee BioMed Central Ltd. This is an open access article distributed under the terms of the Creative Commons Attribution License (http://creativecommons.org/licenses/by/2.0), which permits unrestricted use, distribution, and reproduction in any medium, provided the original work is properly cited. 